\title{
Examination of the Leaf-Drop Symptom of Virus-Infected Potato Using Anther Culture-Derived Haploids
}

\author{
J. P. T. Valkonen, V-M. Rokka, and K. N. Watanabe
}

First author: Department of Plant Biology, Genetic Centre, Swedish University of Agricultural Sciences (SLU), P.O. Box 7080, S-75007 Uppsala, Sweden; second author: Agricultural Research Centre, Institute of Soil and Crop Science, Plant Breeding Section, FIN-31600 Jokioinen, Finland; and third author: Faculty of Biosciences and Technology, Kinki University, Uchita, Wakayama, 649-64, Japan. Accepted for publication 23 June 1998.

\section{ABSTRACT}

Valkonen, J. P. T., Rokka, V-M., and Watanabe, K. N. 1998. Examination of the leaf-drop symptom of virus-infected potato using anther culturederived haploids. Phytopathology 88:1073-1077.

Necrotic lesions and vein necrosis characteristic of the hypersensitive response (HR) controlled by the dominant resistance gene $N y$ develop in potato $\mathrm{cv}$. Pito after infection with potato virus $\mathrm{Y}$ ordinary strain $\left(\mathrm{PVY}^{\mathrm{O}}\right)$ at a low temperature $\left(16 / 18^{\circ} \mathrm{C}\right.$ night/day). In contrast, at high temperatures $\left(19 / 24^{\circ} \mathrm{C}\right.$ night/day), large coalesced lesions develop in the lower infected leaves, which wither and remain hanging from stems forming the leafdrop symptom; mosaic symptoms with no necrosis also develop in the top leaves. The genetic basis of the leaf-drop symptom and its dependence on temperature were examined using a novel approach involving 58 haploids $(2 \mathrm{n}=24)$ derived from 'Pito' $(2 \mathrm{n}=48)$ through anther culture. These haploids and 'Pito' were graft-inoculated with $\mathrm{PVYO}$ at $19 / 24$ to $25^{\circ} \mathrm{C}$ (night/day). Necrotic symptoms were expressed in 28 haploids, of which 18 haploids (phenotype class $\mathrm{N}$ ) developed top necrosis, vein necrosis, or both and necrotic lesions that are characteristic of HR. Ten haploids showed leaf drop similar to 'Pito' (phenotype class LD). Thirty haploids were susceptible and showed only mosaic symptoms (phenotype class S). These data indicated that necrosis was induced by a single dominant gene, $N y$, in the simplex condition. However, the three distinct phenotypic classes $(\mathrm{N}$, $\mathrm{LD}$, and S) among the haploids grown under the same environmental conditions showed that another locus (gene) was involved in modifying the HR triggered by $N y$. Data suggested that this locus contains a dominant temperature-dependent modifier $(\mathrm{Tdm})$ gene that alters the expression of PVY-induced HR at higher temperatures, resulting in leaf drop.
Potato Y potyvirus (PVY) is globally the second most important viral pathogen (after potato leaf roll luteovirus) of cultivated potato (Solanum tuberosum L., $2 \mathrm{n}=4 \mathrm{x}=48$ ) and can cause yield losses up to $80 \%$ in susceptible varieties or in coinfections with other viruses. The properties of PVY have been reviewed $(9,24)$. The leaf-drop symptom was first described by Dykstra (11) in the 1930s in potato cv. President infected with PVY. Systemically infected leaves at an intermediate position of the stem developed expanding necrotic lesions, vein necrosis, or both, and the entire leaf became necrotic and withered. Necrotic leaves remained attached to the stem, hanging down and providing plants with the characteristic leaf-drop habitus, while the plant top remained alive and showed mosaic symptoms. Leaf drop developed following current-season infection with PVY, but it was also observed in plants that grew from infected tubers. Leaf drop was later found to be the characteristic symptom caused by the PVY isolates belonging to the ordinary strain group of PVY $\left(\mathrm{PVY}^{\mathrm{O}}\right)$ in potato cultivars $(9,10,14)$.

Many potato cultivars develop leaf drop following infection with $\mathrm{PVY}^{\mathrm{O}}$ and are usually classified as susceptible, because the growth of plants is very retarded and yield is reduced. In some cultivars, necrotic local lesions develop following mechanical inoculation, and necrotic symptoms may or may not appear in the noninoculated leaves. However, the plants grown from tubers of these mechanically inoculated plants develop leaf-drop and mosaic symptoms (29). Development of necrotic local lesions indicates expression of the single dominant gene $\mathrm{Ny}$ that controls the hypersensitive response (HR) to PVY ${ }^{\mathrm{O}}(6-8,14,21-23)$. Thus, leaf drop may also be associated with the HR controlled by $N y$. This concept is supported by studies of Cockerham (6), who reported that when a dominant gene

Corresponding author: J. P. T. Valkonen; E-mail address: jari.valkonen@vbiol.slu.se

Publication no. P-1998-0812-01R

(C) 1998 The American Phytopathological Society for HR (lethal necrosis) to PVY was transferred from the wild species $S$. microdontum $(2 \mathrm{n}=2 \mathrm{x}=24)$ and $S$. demissum $(2 \mathrm{n}=6 \mathrm{x}=$ $72)$ to tetraploid $S$. tuberosum material $(2 n=4 x=48)$, the genes for hypersensitivity "lost their dominant effects in the genetic background of tetraploids" and were "identical with the genes which determine necrotic response to virus $\mathrm{Y}$ in cultivated varieties." He observed a range of phenotypic responses in progenies including necrotic local lesions without systemic infection, lethal necrosis, nonlethal systemic necrosis, leaf-drop and mosaic symptoms, and minor necrotic lesions in the systemically infected leaves.

'Pito' is the most prevalent local staple potato variety in Finland. It is susceptible to $\mathrm{PVY}^{\mathrm{O}}$, the tobacco veinal necrosis strain group of PVY $\left(\mathrm{PVY}^{\mathrm{N}}\right)$, and potato A potyvirus $(16,29)$. Stocks become infected with these viruses in the field $(2,16)$. Current-season infection with $\mathrm{PVY}^{\mathrm{O}}$ results in mosaic symptoms, and secondary (tuber-borne) infection results in severe mosaic and growth retardation $(16,29)$. No necrotic lesions have been reported in the mechanically inoculated leaves of 'Pito', but leaf drop has been occasionally observed in the greenhouse during the winter following infection with some $(16,29)$, but not all, isolates of $\mathrm{PVY}^{\mathrm{O}}(31)$. A recent study (28) has shown that leaf drop in 'Pito' develops following $\mathrm{PVY}^{\mathrm{O}}$ infection specifically at higher temperatures $\left(19 / 24^{\circ} \mathrm{C}\right.$ night/day), whereas vein necrosis and necrotic lesions characteristic of $\mathrm{Ny}$ expression develop at low temperatures $\left(16 / 18^{\circ} \mathrm{C}\right.$ night/day), which suggests that 'Pito' carries and expresses the gene $\mathrm{Ny}$ in a temperature-dependent manner. Other examples of temperature-dependent expression of HR to virus infection in potato include the genes $N x$ and $\mathrm{Nb}$ that control the HR to potato $\mathrm{X}$ potexvirus in tetraploid potato cultivars, resulting in the development of necrotic local lesions at 16 and $20^{\circ} \mathrm{C}$, but not at $25^{\circ} \mathrm{C}(1)$. Furthermore, $\mathrm{PVY}^{\mathrm{N}}$ induces development of necrotic lesions in the inoculated leaves and top necrosis in systemically infected $S$. sparsipilum and $S$. sucrense at $16 / 18^{\circ} \mathrm{C}$ (night/day), whereas leaf drop develops at 19 to $24^{\circ} \mathrm{C}(28)$. It is known that development of necrotic symptoms follows after 
activation of the HR and depends on the genotype and physiological condition of the host as well as environmental conditions such as temperature and light $(1,10,33,34)$, but the genetic basis of temperature dependence has not been reported.

The aim of this study was to advance the understanding of the genetic basis of the leaf-drop symptom that develops in 'Pito' in a temperature-dependent manner. This question was approached using a novel and unusual strategy. Haploids $(2 n=24)$ were extracted from tetraploid 'Pito' $(2 \mathrm{n}=48)$ through anther culture and tested for symptom development following infection with $\mathrm{PVY}^{\mathrm{O}}$ (use of the term haploid for sporophytes with gametic chromosome number follows previously established terminology [18,32]). Hence, the gametic output of 'Pito' could be tested for symptom expression directly, avoiding any inference by genes that would be donated to hybrids by the other parent in crosses.

\section{MATERIALS AND METHODS}

Plant material. Tubers of potato 'Pito' were originally obtained from the pathogen-tested potato collection at the Seed Potato Center, Tyrnävä, Finland, and were maintained as in vitro shoot cultures. Haploid lines $(2 n=2 x=24)$ of 'Pito' $(2 n=4 x=48)$ were produced through anther culture at the Finnish Agricultural Research Centre, Institute of Soil and Crop Science, Plant Breeding Section. Anthers were isolated from greenhouse-grown 'Pito' and cultured in vitro, and plants were regenerated following the procedures and under the experimental conditions previously described $(20,26)$. Regenerated plants were multiplied by internodal cuttings in vitro. Ploidy levels of the regenerants were determined by measuring the DNA content of nuclei ( $2 \mathrm{C}$ value) extracted from leaves of in vitro plantlets and stained with propidium iodide (PI) using a FACSort flow cytometer (Becton-Dickinson, San Jose, CA) following a previously described procedure (3). PI-stained chicken red blood cells $(2 \mathrm{C}=2.33 \mathrm{pg})$ were added to plant nuclei as internal standards (3). Ploidy levels of several regenerants were also determined by chromosome counting in root tip cells as previously described (15). For virus tests, in vitro plantlets of the haploids and 'Pito' were transferred to soil and grown in a greenhouse under natural daylight supplemented with illumination from sodium halide lamps (photoperiod $18 \mathrm{~h} ; 150 \mu \mathrm{mol} \mathrm{s} \mathrm{s}^{-1} \mathrm{~m}^{-2}$, measured at crop height). Temperatures were recorded daily at the level of plant tops. The daily minimum temperature was $19^{\circ} \mathrm{C}$, whereas the daily maximum temperatures were 24 to $25^{\circ} \mathrm{C}$.

Inoculation and detection of PVY ${ }^{\circ}$. The isolate of $P V Y^{O}$ used in this study has been previously characterized $(19,29)$. PVY infected 'Pito' plants were used as sources of infected shoots for graft-inoculation. They were produced by mechanically inoculating 'Pito' plants with PVY ${ }^{\mathrm{O}}$, cutting down the shoots as soon as mosaic symptoms appeared, and using the axillary shoots for grafting. Graft-inoculation was carried out as previously described (31) by side-grafting one apical shoot of PVYO -infected 'Pito' onto each test plant. Two plants per haploid clone were tested in two experiments.

Polyclonal antibodies and alkaline phosphatase-conjugated antibodies to PVY were obtained from Boehringer-Mannheim $\mathrm{GmbH}$ (Mannheim, Germany). They were used for detection of $\mathrm{PVY}^{\mathrm{O}}$ in the uppermost fully expanded leaves by double-antibody sandwich enzyme-linked immunosorbent assay (DAS-ELISA) as previously described (29).

\section{RESULTS}

Ploidy and morphology of the anther culture-derived regenerants. Putatively androgenetic genotypes obtained though anther culture of 'Pito' were analyzed for nuclear DNA content (2C values) by flow cytometry. Also, chromosome numbers were determined microscopically in many haploids, and results were consistent with flow cytometry. A few genotypes were triploid or tetraploid and were excluded from virus tests. No gross differences in morphol- ogy were observed, except nine genotypes were dwarfed and slow growing and, therefore, were not used for virus tests.

Phenotypic responses following graft-inoculation with PVYO. Three plants of each tissue culture regenerant and 'Pito' were graftinoculated with $\mathrm{PVY}^{\mathrm{O}}$ in the greenhouse in two experiments under the conditions described above. The 58 haploids were placed into two groups according to phenotypic reactions following graft-inoculation with $\mathrm{PVY}^{\mathrm{O}}$. Group 1 contained 28 haploids that all showed necrotic symptoms. This group was further divided in two phenotypic classes, $\mathrm{N}$ and LD. Class N (18 haploids) developed vein necrosis, necrotic spots, or both by 14 to 16 days after inoculation and, in most cases, top necrosis a few days later. Class LD (10 haploids) developed leaf drop in the lower infected leaves and mosaic symptoms in the top leaves (Fig. 1). In the leaves showing mosaic symptoms, PVY titers were similar to those of 'Pito' as determined by DAS-ELISA (data not shown). All tested plants of a given haploid line showed similar symptoms consistently. Group 2 contained 30 haploids that showed only mosaic symptoms with no necrosis, had high PVY titers similar to those in the top leaves of 'Pito' as measured by DAS-ELISA (data not shown), and were considered to be susceptible to PVYO (class S) (Fig. 1). Symptom development was observed up to 31 days after inoculation, but no change in the earlier determined phenotypic class was observed. Thus, the proportion of necrotic to nonnecrotic phenotypes was 28:30 among the haploids, and the proportion of the three phenotypic classes N, LD, and S was 18:10:30, respectively. 'Pito' developed leaf drop.

Genetic modeling. According to a previous study (28), 'Pito' probably carries a resistance gene similar to $N y$ that controls the HR to $\mathrm{PVY}^{\mathrm{O}}$, but the development of necrotic symptoms following infection is dependent on temperature. By genetic modeling, we tested whether induction of necrotic symptoms was attributable to a single $N y$-like gene, and whether this gene was temperature sensitive and, thus, partially dominant at different temperatures or whether another genetic locus (gene) was involved and altered the symptom expression. Because the gametic output from a tetraploid is the same as the haploid genotype, the gametic genotypes can be used for estimating segregation of genes in a population of haploids derived from a given tetraploid genotype (18). We refer below to the genetic models that were tested, but explain in detail only those in which the hypothetical and observed segregation showed a high goodness of fit.

The allelic number of $N y$, whether $N y$ was dominant or partially dominant and whether $N y$ showed chromosome or chromatid segregation, was first tested. Assuming that $N y$ was dominant and in simplex condition, the expected haploid genotype ratio would be $N y / N y: N y / n y: n y / n y=0: 1: 1$ and 1:12:15 in the case of chromosome and chromatid segregation, respectively, and the phenotype ratio of necrotic $\left(\mathrm{N}\right.$ or LD) and susceptible $(\mathrm{S})$ haploids would be 1:1 $\left(\chi^{2}=\right.$ $\left.0.069 ; \chi_{1,0.005}^{2}=7.88\right)$ and $13: 15\left(\chi^{2}=0.079 ; \chi_{1,0.005}^{2}=7.88\right)$, respectively. Both expected phenotype ratios are consistent with the observed phenotype ratio (28:30). Further studies are needed to distinguish between the two segregation models. Other studies have reported other PVY resistance genes that show chromatid segregation in potato $(8,17)$. No model assuming partial dominance of $N y$ or a duplex or triplex condition of $N y$ was consistent with our data.

Because our phenotypic data could be categorized to three distinct classes (N, LD, and S) instead of two classes (N and $\mathrm{S}$ ), it was apparent, for the reasons mentioned above, that another locus (gene) was affecting the phenotypic outcome of the HR triggered by $N y$. Existence of a temperature-dependent modifier $(\mathrm{Tdm})$ gene was postulated, and different hypothetical gametic outcomes were predicted in the cases of dominant or recessive inheritance, simplex or duplex condition, chromosome or chromatid segregation, and with or without assumption of gene linkage between $T d m$ and $N y$. Because the postulated $T d m$ would confer a distinguishable phenotype only in the haploids expressing $N y$, as the postulated phenotypic effect of $T d m$ is the development of leaf drop in such 

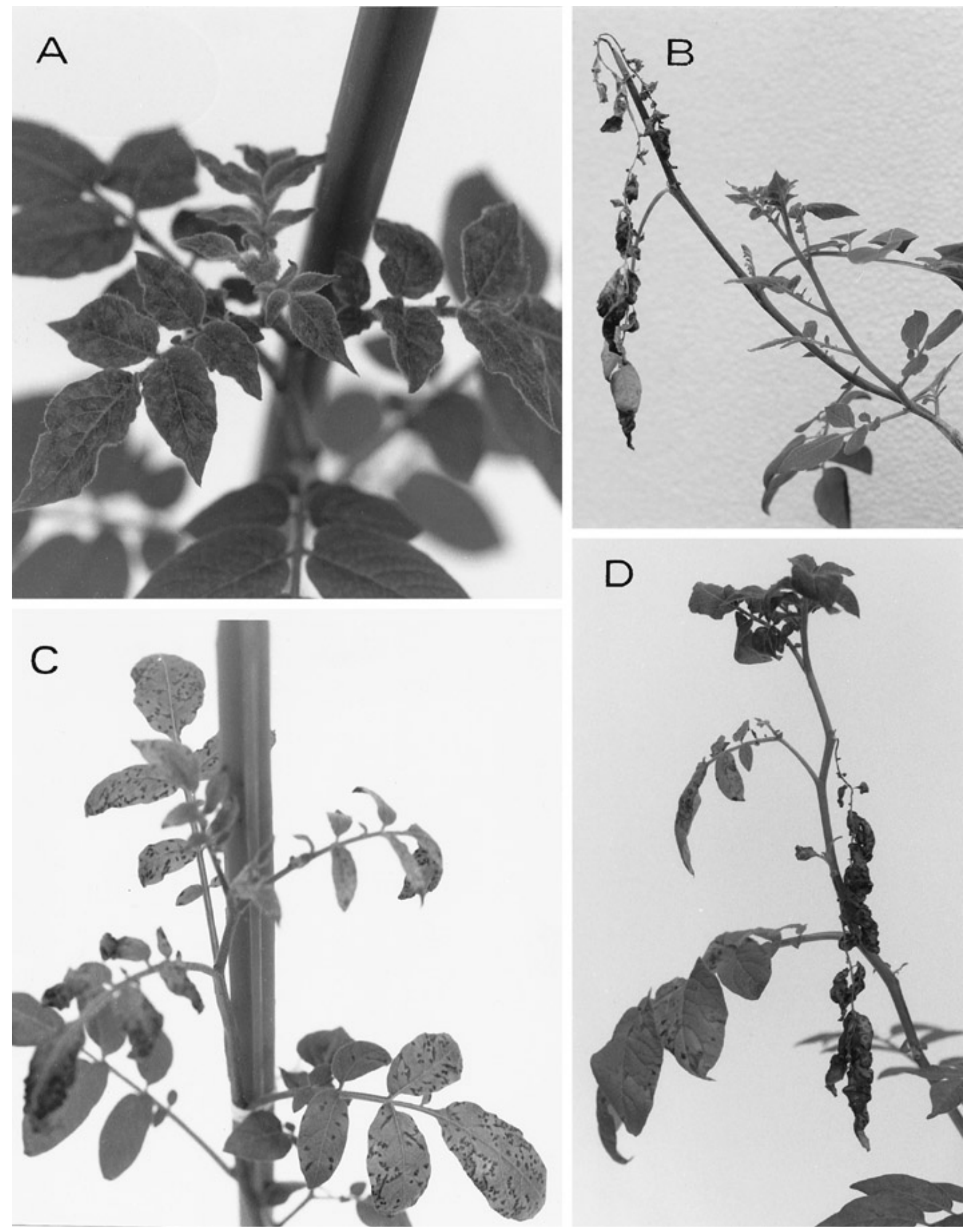

Fig. 1. Symptom expression in haploids of 'Pito' 18 days after graft-inoculation with potato virus $\mathrm{Y}$ ordinary strain (PVYO). A, Haploid line 157 (phenotypic class S) showing mosaic symptoms. B, Haploid line 71 (class N) showing top necrosis. C, Haploid line 18 (class N) showing vein necrosis and necrotic lesions. D, Haploid line 21 (class LD) showing leaf-drop and mosaic symptoms. 
haploids, segregation of $T d m$ in the phenotypic class $\mathrm{S}$ could not be observed. Ten of the twenty-eight haploids expressing $N y$ (i.e., necrotic symptoms) developed leaf drop and, thus, showed the effect of the postulated $T d m$, but it is plausible that the phenotypic class $\mathrm{S}$ also contained haploids with $T d m$. Taking this into consideration, only the models assuming $T d m$ was dominant and in simplex condition showed good probability of goodness of fit of the hypothesis. Assuming chromatid segregation, the expected haploid genotype ratio was $(N y / N y+12 N y / n y+15 n y / n y)(T d m / T d m+12 T d m / t d m+$ $15 \mathrm{tdm} / \mathrm{tdm})=\mathrm{Ny} / \mathrm{Ny} \mathrm{Tdm} / \mathrm{Tdm}+12 \mathrm{Ny} / \mathrm{Ny} \mathrm{Tdm} / \mathrm{tdm}+15 \mathrm{Ny} / \mathrm{Ny}$ tdm/tdm +12 Ny/ny Tdm/Tdm +144 Ny/ny Tdm/tdm $+180 \mathrm{Ny} /$ ny tdm/tdm +15 ny/ny Tdm/Tdm +180 ny/ny Tdm/tdm +225 ny/ny $t d m / t d m$, and the expected phenotypic ratio N/LD/S = 195:169:420. Assuming chromosome segregation of $T d m$, the expected phenotypic ratio was $\mathrm{N} / \mathrm{LD} / \mathrm{S}=1: 1: 2$. Both models show a good probability of goodness of fit $\left(\chi^{2}=1.42\right.$ and 2.28 , respectively; $\chi_{2,0.05}^{2}=$ 5.99 ) with the observed phenotype ratio $\mathrm{N} / \mathrm{LD} / \mathrm{S}=18: 10: 30$. In the case of coupling phase linkage between $N y$ and $T d m$, the expected phenotypic ratio was N/LD/S $=2 / 3 q:(1-2 / 3 q): 1$, in which $q$ is the recombination frequency. Coupling phase linkage with high recombination frequency would be consistent with our data (e.g., $q=1$ results in phenotypic segregation $\mathrm{N} / \mathrm{LD} / \mathrm{S}=2: 1: 3 ; \chi^{2}=0.137$ ), but independent assortment of $\mathrm{Tdm}$ and $\mathrm{Ny}$ cannot be ruled out.

\section{DISCUSSION}

A previous study (28) has shown that the types of necrotic symptoms that develop in tetraploid 'Pito' following infection with $\mathrm{PVY}^{\mathrm{O}}$ depend on temperature. At the lower temperature of 16 to $18^{\circ} \mathrm{C}$, necrotic lesions and vein necrosis develop in leaves, which is characteristic for the expression of $\operatorname{HR}(6,7,14,22,31)$. The low temperature needs to be maintained for the efficient expression of HR, shown as the development of necrotic lesions in 'Pito', whereas higher temperatures alter the symptom expression toward development of leaf drop without distinct lesions. These results from the growth-room experiments (28) are consistent with the results from the greenhouse in this study and the previous study (28) in which temperatures varied between 19 and $25^{\circ} \mathrm{C}$ and $\mathrm{PVY}^{\mathrm{O}}$-infected 'Pito' developed leaf-drop symptom.

Production of 58 haploid plants from the tetraploid 'Pito' through anther culture permitted genetic modeling of the regulation of the two types of PVY-induced necrotic symptoms and their dependence on temperature. Production of potato haploids via anther culture is advantageous over using $S$. phureja as a pollinator for haploid induction. This is because, in contrast to the previous belief, the pollinator can donate DNA $(5,35)$ including genes for virus resistance $(27,30)$ to the haploids, which hampers interpretation of data from genetic studies using haploids. Another difficulty often encountered with haploid production is that it is difficult to produce sufficiently large numbers of haploids from the genotype of interest $(18,20)$ and genetic studies are, therefore, not possible. This problem was overcome in our study. The nine dwarfed haploids not included in virus tests are responsive to the exogenous application of gibberellic acid, which restores normal growth rate and phenotype (J. P. T. Valkonen, unpublished data). Therefore, dwarfism of these plants may result from a recessive mutation in a gene of the gibberellic acid-synthesis pathway and is probably not due to somaclonal variation, which is currently being investigated in another study.

A total of 28 haploids showed necrotic symptoms, whereas 30 haploids were affected by mosaic symptoms following graft-inoculation with $\mathrm{PVY}^{\mathrm{O}}$. These data indicated that the necrotic symptoms in 'Pito' that developed following infection with $\mathrm{PVY}^{\mathrm{O}}$ were triggered by a single dominant gene, $N y$, in simplex condition, which is consistent with the genetic control of the PVY-induced HR in many potato species studied using crosses $(6-8,14,17,22$, $23)$. However, two discrete classes of necrotic symptoms were produced among the haploids under the same environmental condi- tions in this study. Because no model in which higher temperatures were assumed to suppress $N y$ directly was consistent with the phenotypic data, another gene locus $(T d m)$ was postulated. The fitness of the digenic model was significant, irrespective of whether chromosome or chromatid segregation of the modifier gene was assumed and also whether $T d m$ and $N y$ loci were linked or not.

Leaf drop was described long ago (11) as a characteristic symptom of PVY-infected potatoes, but it has been unclear whether or not the leaf-drop symptom is due to resistance gene expression. Our study suggests that the potato varieties that develop leaf drop carry the gene $N y$, but they also carry a modifier gene such as $T d m$ in 'Pito', affecting the symptom expression. This conclusion is supported by Cockerham (6) and Ross (22), who found that the genes for hypersensitive and extreme resistance to PVY derived from diploid wild potato species lost dominance in many progenies following transfer to susceptible tetraploid potatoes. Ross (22) concluded that "polygenes brought in by $S$. tuberosum parents seem to intervene in these cases." Our study does not exclude the effect of polygenes on $N y$, but our model provides significant evidence for one modifier locus with a major effect. Similarly, factors other than temperature may also affect the modifier-gene activity, but according to our study, temperature has a major effect on the type of symptoms that develop in PVYO ${ }^{\mathrm{O}}$-infected 'Pito'. Previous studies on HR-induced membrane leakage have demonstrated that necrosis is not the basis, but a response, to the HR resistance phenomenon and that HR is sensitive to high temperature (34). It is also hypothesized that, in 'Pito', the expression of $\mathrm{Ny}$ and HR are rendered less efficient through expression of the $T d m$ modifier gene at higher temperatures, consistent with the high PVY titers, mosaic symptoms, and absence of necrosis observed in the top leaves of haploids and 'Pito' expressing the postulated $T d m$ gene.

Molecular localization and isolation of resistance genes that specifically recognize PVY and trigger a resistance response in potato are in progress $(4,12,13)$, and understanding of the initial recognition between pathogens, including viruses, and resistance genes is increasing (25). However, downstream control of the resistance responses and signal transduction involving many host genes are largely uncharacterized. Therefore, the drastic effects on HR expression and the discrete LD phenotype make $T d m$ an attractive target for molecular localization and characterization in further studies.

\section{ACKNOWLEDGMENTS}

We thank the following for financial support: The Academy of Finland (grants 6994 and 36256) to J. P. T. Valkonen, The Finnish Ministry of Agriculture and Forestry to V-M. Rokka, and the Forret Frosty Hill International Agriculture Award to K. N. Watanabe. We also thank K. Salmi for assistance in tissue culture and chromosome counting, and S. A. Slack for critically reviewing the previous version of this manuscript.

\section{LITERATURE CITED}

1. Adams, S. E., Jones, R. A. C., and Coutts, R. H. A. 1986. Effect of temperature on potato virus $\mathrm{X}$ infection in potato cultivars carrying different combinations of hypersensitivity genes. Plant Pathol. 35:517-526.

2. Anonymous. 1994. Operations of the State Seed Testing Station in 19881993. (In Finnish.) Loimaan Kirjapaino, Loimaa, Finland.

3. Arumuganathan, K., and Earle, E. D. 1991. Estimation of nuclear DNA content of plants by flow cytometry. Plant Mol. Biol. Rep. 9:229-233.

4. Brigneti, G., Garcia-Mas, J., and Baulcombe, D. C. 1997. Molecular mapping of the potato virus $\mathrm{Y}$ resistance gene $R y_{\text {sto }}$ in potato. Theor. Appl. Genet. 94:198-203.

5. Clulow, S. A., Wilkinson, M. J., Waugh, R., Baird, E., DeMaine, M. J., and Powell, W. 1991. Cytological and molecular observations on Solanum phureja-induced dihaploid potatoes. Theor. Appl. Genet. 82:545-551.

6. Cockerham, G. 1952. Breeding for resistance to potato viruses. Pages 37-39 in: Proc. Conf. Potato Virus Dis. E. Streutgers, A. B. R. Beemster, J. Walrave, and J. P. H. van der Want, eds. Staatsdrukkerij, the Netherlands.

7. Cockerham, G. 1957. Experimental breeding in relation to virus resistance. Pages 199-203 in: Proc. Conf. Potato Virus Dis., 3rd. F. Quak, J. Dijkstra, A. B. R. Beemester, and J. P. H. van der Want, eds. H. Veenman \& Zoonen, Wageningen, the Netherlands. 
8. Cockerham, G. 1970. Genetical studies on resistance to potato viruses $\mathrm{X}$ and Y. Heredity 25:309-348.

9. De Bokx, J. A., and Huttinga, H. 1981. Potato virus Y. CMI (Commonw. Mycol. Inst.)/AAB (Assoc. Appl. Biol.) Descr. Plant Viruses No. 242.

10. De Bokx, J. A., and van der Want, J. P. H. 1987. Viruses of Potatoes and Seed-Potato Production. PUDOC, Wageningen, the Netherlands.

11. Dykstra, T. P. 1939. A study of viruses infecting European and American varieties of the potato, Solanum tuberosum. Phytopathology 29:40-67.

12. Hämäläinen, J. H., Sorri, V., Watanabe, K. N., Gebhardt, C., and Valkonen, J. P. T. 1998. Molecular examination of a chromosome region that controls resistance to potato $\mathrm{Y}$ and A potyviruses in potato. Theor. Appl. Genet. 96: 1036-1043.

13. Hämäläinen, J. H., Watanabe, K. N., Valkonen, J. P. T., Arihara, A., Plaisted, R. L., Pehu, E., Miller, L., and Slack, S. A. 1997. Mapping and marker-assisted selection for a gene for extreme resistance to potato virus Y. Theor. Appl. Genet. 94:192-197.

14. Jones, R. A. C. 1990. Strain group specific and virus specific hypersensitive reactions to infection with potyviruses in potato cultivars. Ann. Appl. Biol. 117:93-105.

15. Karp, A., Risiott, R., Jones, M. G. K., and Bright, S. W. J. 1984. Chromosome doubling in monohaploid and dihaploid potatoes by regeneration from cultured leaf explants. Plant Cell Tissue Organ Cult. 3:363-373.

16. Kurppa, A. 1983. Potato viruses in Finland and their identification. J. Sci. Agric. Soc. Finl. 55:183-301.

17. Muñoz, F. J., Plaisted, R. L., and Thurston, H. D. 1975. Resistance to potato virus $\mathrm{Y}$ in Solanum tuberosum spp. andigena. Am. Potato J. 52: 107-115.

18. Ortiz, R., and Peloquin, S. J. 1994. Use of 24-chromosome potatoes (diploids and dihaploids) for genetical analysis. Pages 133-154 in: Potato Genetics. J. E. Bradshaw and G. R. MacKay, eds. CAB International, Wallingford, Oxon, United Kingdom.

19. Pehu, T. M., Mäki-Valkama, T. K., Valkonen, J. P. T., Koivu, K. T., Lehto, K. M., and Pehu, E. 1995. Potato plants transformed with a potato virus Y P1 gene sequence are resistant to PVYO . Am. Potato J. 72:523-532.

20. Rokka, V-M., Pietilä, L., and Pehu, E. 1996. Enhanced production of dihaploid lines via anther culture of tetraploid potato (Solanum tuberosum L. ssp. tuberosum) clones. Am. Potato J. 73:1-12.

21. Ross, H. 1952. Studies on mosaic resistance in the potato. Pages 40-62 in: Proc. Conf. Potato Virus Dis. Staatsdrukkerij, the Netherlands.

22. Ross, H. 1957. Inheritance of extreme resistance to virus Y in Solanum stoloniferum and its hybrids with Solanum tuberosum. Pages 204-211 in: Proc. Conf. Potato Virus Dis., 3rd. F. Quak, J. Dijkstra, A. B. R. Beemester, and J. P. H. van der Want, eds. H. Veenman \& Zoonen, Wageningen, the Netherlands.

23. Ross, H. 1986. Potato breeding-Problems and perspectives. J. Plant Breed. Suppl. 13.

24. Shukla, D. D., Ward, C. W., and Brunt, A. A. 1994. The Potyviridae. CAB International, Wallingford, Oxon, United Kingdom.

25. Somssich, I. E., and Hahlbrock, K. 1998. Pathogen defence in plants-A paradigm of biological complexicity. Trends Plant Sci. 3:86-90.

26. Tiainen, T. K. 1992. The influence of culture conditions on anther culture response of commercial varieties of Solanum tuberosum L. Plant Cell Tissue Organ Cult. 30:211-219.

27. Tommiska, J., Hämäläinen, J. H., Watanabe, K. N., and Valkonen, J. P. T. 1998. Mapping of the gene $N x_{p h u}$ that controls hypersensitive resistance to potato virus $\mathrm{X}$ in Solanum phureja IvP35. Theor. Appl. Genet. 96: 840-843.

28. Valkonen, J. P. T. 1997. Novel resistances to potyviruses in tuber-bearing potato species, and temperature-sensitive expression of hypersensitive resistance to potato virus Y. Ann. Appl. Biol. 130:91-104.

29. Valkonen, J., and Mäkäräinen, E. 1993. Symptom expression and accumulation of potato virus $\mathrm{Y}\left(\mathrm{PVY}^{\mathrm{O}}\right)$ and potato leaf roll virus in thirteen potato cultivars. Agric. Sci. Finl. 2:33-40.

30. Valkonen, J. P. T., Orillo, M., Slack, S. A., Plaisted, R. L., and Watanabe, K. N. 1995. Resistance to viruses in F1 hybrids produced by direct crossing between diploid Solanum series Tuberosa and diploid S. brevidens (series Etuberosa) using $S$. phureja for rescue pollination. Plant Breed. 114:421-426.

31. Valkonen, J. P. T., Slack, S. A., and Plaisted, R. L. 1994. Use of the virus strain group concept to characterize the resistance to PVX and PVYO in the potato cv. Allegany. Am. Potato J. 71:507-516.

32. Watanabe, K. N. 1994. Molecular genetics. Pages 213-235 in: Potato Genetics. J. E. Bradshaw and G. R. MacKay, eds. CAB International, Wallingford, Oxon, United Kingdom.

33. Weintraub, M., Ragetli, H. W. J., and John, V. T. 1967. Some conditions affecting the intracellular arrangement and concentration of tobacco mosaic particles in local lesions. J. Cell Biol. 35:183-192.

34. Westeijn, E. A. 1981. Lesion growth and virus localization in leaves of Nicotiana tabacum cv. Xanthi nc. after inoculation with tobacco mosaic virus and incubation alternately at $22^{\circ} \mathrm{C}$ and $32^{\circ} \mathrm{C}$. Physiol. Plant Pathol. 18:357-369.

35. Wilkinson, M. J., Bennett, S. T., Clulow, S. A., Allainguillaume, J., Harding, K., and Bennett, M. D. 1995. Evidence for somatic translocation during potato dihaploid induction. Heredity 74:146-151. 